\title{
Bridged Nucleic Acids Reloaded
}

\author{
Alfonso Soler-Bistué $^{1}{ }^{\circledR}$, Angeles Zorreguieta ${ }^{2}$ and Marcelo E. Tolmasky ${ }^{3, *}$ \\ 1 Instituto de Investigaciones Biotecnológicas Dr. Rodolfo A. Ugalde, Instituto Tecnológico de Chascomús, \\ CONICET, Universidad Nacional de San Martín, San Martín 1650, Argentina; asoler@iib.unsam.edu.ar \\ 2 Fundación Instituto Leloir, IIBBA-CONICET, Buenos Aires C1405BWE, Argentina; azorreguieta@leloir.org.ar \\ 3 Center for Applied Biotechnology Studies, Department of Biological Science, California State University \\ Fullerton, Fullerton, CA 92834-6850, USA \\ * Correspondence: mtolmasky@fullerton.edu; Tel.: +1-657-278-5263
}

Academic Editor: Josef Jampilek

Received: 31 May 2019; Accepted: 18 June 2019; Published: 21 June 2019

check for updates

\begin{abstract}
Oligonucleotides are key compounds widely used for research, diagnostics, and therapeutics. The rapid increase in oligonucleotide-based applications, together with the progress in nucleic acids research, has led to the design of nucleotide analogs that, when part of these oligomers, enhance their efficiency, bioavailability, or stability. One of the most useful nucleotide analogs is the first-generation bridged nucleic acids (BNA), also known as locked nucleic acids (LNA), which were used in combination with ribonucleotides, deoxyribonucleotides, or other analogs to construct oligomers with diverse applications. However, there is still room to improve their efficiency, bioavailability, stability, and, importantly, toxicity. A second-generation BNA, BNA ${ }^{\mathrm{NC}}\left(2^{\prime}-\mathrm{O}, 4^{\prime}\right.$-aminoethylene bridged nucleic acid), has been recently made available. Oligomers containing these analogs not only showed less toxicity when compared to LNA-containing compounds but, in some cases, also exhibited higher specificity. Although there are still few applications where $\mathrm{BNA}^{\mathrm{NC}}$-containing compounds have been researched, the promising results warrant more effort in incorporating these analogs for other applications. Furthermore, newer BNA compounds will be introduced in the near future, offering great hope to oligonucleotide-based fields of research and applications.
\end{abstract}

Keywords: oligonucleotides; bridged nucleic acids; locked nucleic acids; antisense; antibiotic resistance; hypercholesterolemia; myotonic dystrophy; CRISPR; Cas9; hematologic malignancies

\section{Oligonucleotides and Analogs}

Oligonucleotides are short oligomers composed of ribonucleotides or deoxyribonucleotides. They have multiple uses in basic research, diagnostics, and therapeutics. Their most basic and widespread use is in primer-based techniques, which are used in the most diverse kinds of biological research or development projects, such as polymerase chain reaction (PCR), library construction, single nucleotide polymorphisms detection, gene silencing, tiling arrays, and many others. Besides these applications, oligonucleotides were also found to be immensely useful in the development of gene-silencing techniques. Several approaches were attempted to reduce the undesirable expression of genes, utilizing a variety of strategies, the vast majority of which have in common the utilization of antisense oligonucleotides [1-3]. Many of these compounds are known with different names descriptive of their mechanism of action, like external guide sequences [4,5], ribozymes [6,7], aptamers [8,9], short interfering RNA [10-12], and microRNA [13,14]. These compounds interfere with gene expression by steric hindrance of transcription or translation, or by inducing enzymatic cleavage of the target mRNA $[3,4,11,13]$. The rapid increase in the techniques and applications for which these compounds are integral components, together with the progress in nucleic acid research, led to the design of analogs that are more appropriate to enhance efficiency and achieve specific objectives in each case. 
In general, nucleic acid analogs should a) have higher affinity per nucleotide unit than the cognate sequence, without changing the structure of duplexes, b) be resistant to nucleases, and c) have low toxicity. The first oligonucleotide analogs consisted of relatively minor modifications to the natural counterparts, such as the replacement of an oxygen atom by sulfur (phosphorothioate) $[15,16]$, methyl (methylphosphonate) [17], or amino groups (phosphoramidate) (Figure 1). The value of using nucleotide analogs was illustrated by the first FDA approved antisense drug, fomivirsen, a 21-nucleotide oligomer composed of phosphorothioate units designed for the treatment of cytomegalovirus retinitis [10,18]. Subsequently, more modifications were introduced to the nucleotide molecule, such as adding chemical groups to the $2^{\prime}$ position of the ribose as in $2^{\prime}$-O-methyl compounds (Figure 1) or making more drastic structural changes replacing or modifying the ribose, substituting the nature of the bonds, or modifying the charge of the oligonucleotide, obtaining neutral or cationic derivatives. Examples of these compounds are morpholino phosphoroamidates [19], peptide nucleic acids [20,21], nucleotides with modified nucleobases [22], guanidinium-linked oligomers [23], and locked nucleic acids (LNA) [24] (Figure 1). Exhaustive listings and a description of oligonucleotide analogs and their applications can be found in recent reviews $[3,6,16,23,25-27]$. A derivative of LNA, 2'-O, $4^{\prime}$-aminoethylene bridged nucleic acid (BNA), also known as $2^{\prime}, 4^{\prime}-\mathrm{BNA}^{\mathrm{NC}}\left(\mathrm{BNA}^{\mathrm{NC}}\right.$ ) [28-31] (Figure 1) has been recently introduced and other derivatives have followed or are in development. As a consequence, LNA is considered the earliest generation of bridged nucleic acids (BNA). This review will focus on the properties and applications of $\mathrm{BNA}^{\mathrm{NC}}$-containing compounds.
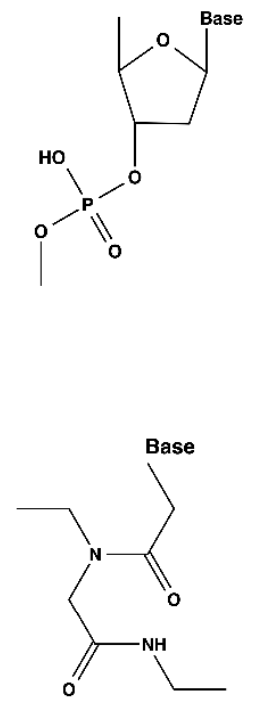

Peptide nucleic acid

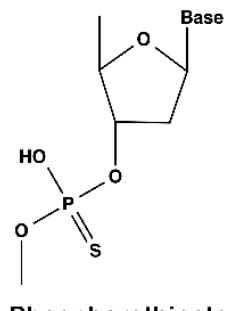

Phosphorothioate
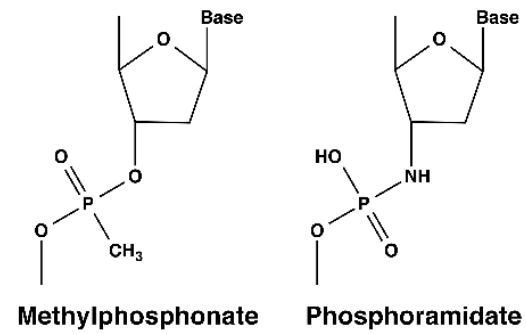
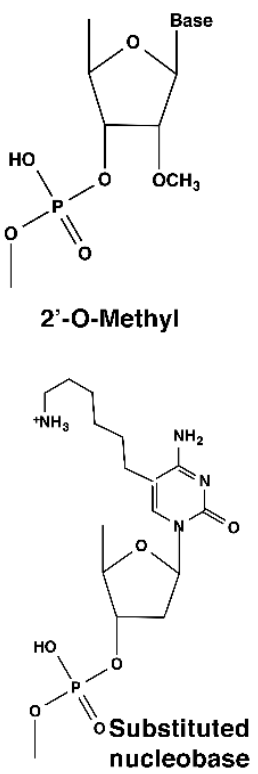
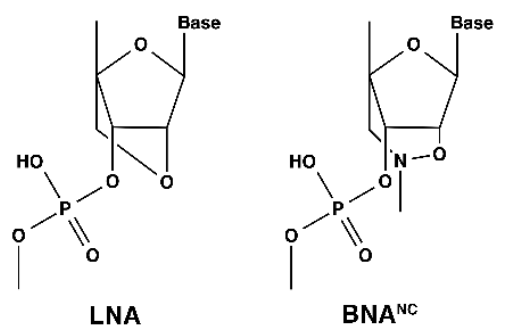

Figure 1. Chemical structures of nucleotide analogs.

\section{LNA-A Brief Overview}

LNA compounds, first introduced in the late 1990s, are bicyclic nucleotide analogs in which the furanose ring is modified by the introduction of a methylene group linking the $2^{\prime}$-oxygen and 
the $4^{\prime}$-carbon $\left(2^{\prime}-O, 4^{\prime}\right.$-methylene- $\beta$-D-ribofuranosyl nucleotides) [32-37]. They are characterized by reduced flexibility of the ribose residue and exist in a locked $N$-type conformation, which favors the formation of stable duplexes with DNA or RNA [34]. Numerous structural and thermal stability studies on complexes formed by LNA oligomers and complementary DNA or RNA oligonucleotides showed higher melting temperatures and specificity when compared to the unmodified isosequential compounds [32,34,37-39]. LNA-containing oligomers are usually synthesized as chimeras containing a combination of ribonucleotide/deoxyribonucleotide or other nucleotide analogs and LNA residues [40-44]. The incorporation of LNA in oligonucleotides leads to melting temperature increases of 3-9 ${ }^{\circ} \mathrm{C}$ per residue [45]. Most LNA-containing chimeras can be classified into two kinds, gapmers and mixmers. Gapmers consist of oligomers where the LNA residues are located at the ends of the compound. Mixmers include the LNA and the other residues interspersed in different configurations throughout the sequence. LNA-containing oligomers have been used for diagnostics and other applications, as probes or primers for hybridization, amplification, mutagenesis, sequencing, and SNP genotyping [46-53], in addition to gene repair [54] and antisense drugs [13,41,42,55]. While the increased binding capacity is advantageous in many antisense applications, it can also be detrimental due to the formation of duplex structures that cannot be recognized as substrates by the enzymes recruited to degrade the target molecule. The high affinity of LNA-containing oligonucleotides can also result in toxic effects due to unspecific off-target binding. Fortunately, recent studies showed that LNA-containing oligomers were innocuous in primates [56] and relatively safe in humans [57-59]. Furthermore, these compounds failed to show genotoxicity [60]. However, these results are far from definitive; other studies showed hepatoxicity [61-64]. Although the toxicity determinations of LNA-containing oligomers are encouraging, case-by-case studies will decide the possibility of development as therapies for human disease. At the moment, numerous potential drugs based on this nucleic acid analog are already in clinical trials (e.g., Miravirsen, MRG-106, and ISTH0036) [10,11]. An obstacle in the development of LNA-containing oligomers as drugs, particularly in silencing prokaryotic genes, is the low or null uptake by bacterial cells. Gymnotic uptake of LNA-containing oligomers was shown in eukaryotic and prokaryotic cells [65-67]. However, although internalization by diverse pathways and reasonable levels of activity were reported in the case of eukaryotic cells [68-72], the levels of internalization into bacterial cells seems not to be enough for productive inhibition of gene expression [66]. LNA-containing oligomers could be delivered to cultured eukaryotic cells by transfection reagents [73-76]. Other strategies to facilitate uptake, such as conjugation to cell penetrating peptides (CPP), which are usually cationic, has been challenging and reports of their utilization to silence gene expression are scarce. Turner et al. [77] reported the attachment of a CPP to an LNA/2'-O-methyl oligonucleotide; cell uptake of this compound was significantly increased with respect to the naked antisense, but levels of inhibition of gene expression were disappointing. An LNA/DNA gapmer designed to target the amikacin resistance $a a c\left(6^{\prime}\right)-I b$ gene mRNA and elicit cleavage by the endogenous RNase P [4] was covalently bound to a CPP. The compound produced a modest reduction in the levels of resistance to amikacin in a clinical Acinetobacter baumannii isolate [78]. LNA-containing compounds were also delivered inside target cells using nanoparticles [79]. An 8-nucleotide LNA oligomer complementary to the oncogenic miR21 included in micelles could be delivered inside cancer cells and induced apoptosis [79]. Furthermore, these assays showed tumor growth inhibition in an animal model [79].

In summary, LNA-containing compounds show great promise as therapeutic agents $[42,80,81]$. However, more research is needed to improve cell penetration while keeping their biological activity and reduced toxicity. Comprehensive descriptions of properties and applications of LNA containing oligomers have been recently published [82-86].

\section{3. $\mathrm{BNA}^{\mathrm{NC}}$}

The success and advantages of LNA-containing oligomers for diverse applications stimulated the search for similar compounds, improving their properties. Many derivatives were recently 
introduced, like BNA ${ }^{\mathrm{NC}}$ with different substitutions at the $\mathrm{N}$ atom (of which a methyl group is the most commonly used to date) (Figure 1) [87], 2'-O,4'-C-ethylene-bridged nucleic acid (ENA) [88], 2'-O,4'-C-methylenoxymethylene-bridged nucleic acid [89], or unlocked nucleic acids (UNA) [90,91]. The bridge in the different BNA compounds can have a different number of members in the ring, the most widely used to date being BNA ${ }^{N C}$, a six-member ring [30,31]. Oligonucleotides containing $\mathrm{BNA}^{\mathrm{NC}}$ are more resistant to nucleases and less toxic than isosequential compounds containing LNA residues, they show high thermal stability and water solubility, and elicit RNase $\mathrm{H}$ degradation of a target RNA [29,62,87,92].

Twelve-mer oligodeoxynucleotides containing a variable number of BNA ${ }^{\mathrm{NC}}$ or LNA residues showed a similar increase in melting temperature $(\mathrm{Tm})$ per modified residue $\left(4.7\right.$ to $\left.7.0{ }^{\circ} \mathrm{C}\right)$ in comparisons of duplex stabilities with complementary single-stranded RNA (ssRNA). However, this was not the case for duplexes with complementary single-stranded DNA (ssDNA) [29]. Increasing the number of $\mathrm{BNA}^{\mathrm{NC}}$ residues in the oligonucleotides did not result in a significant Tm increase $(-1.0$ to $\left.1.8^{\circ} \mathrm{C}\right)$ as was the case when the analog used was LNA $\left(1.3\right.$ to $\left.3.0^{\circ} \mathrm{C}\right)$ [29]. While the Tm values of the unsubstituted oligodeoxynucleotide in duplex with complementary ssRNA was about $5^{\circ} \mathrm{C}$ higher than with complementary ssRNA, the Tm values for substituted oligonucleotides were higher for duplexes with complementary ssRNA. Furthermore, the values were higher for oligonucleotides substituted with $\mathrm{BNA}^{\mathrm{NC}}$ than those that included LNA residues [29]. These results indicate that $\mathrm{BNA}^{\mathrm{NC}}$ residues conferred a higher RNA selective binding affinity to the antisense oligomers. $\mathrm{BNA}^{\mathrm{NC}}$-containing oligonucleotides also showed higher mismatch discrimination properties as well as more stable triplexes than LNA-containing oligomers $[29,93]$. $\mathrm{BNA}^{\mathrm{NC}}$-containing oligonucleotides have the potential to be utilized in diverse applications. In this review, we will focus on their utilization for diverse uses. The different applications of the compounds reviewed in this article are summarized in Table 1.

Table 1. BNA ${ }^{\mathrm{NC}}$ applications.

\begin{tabular}{|c|c|c|c|c|c|}
\hline Organism & Function or Disease & Target & $\begin{array}{l}\text { Chemical Nature of } \\
\text { Oligonucleotide }\end{array}$ & $\begin{array}{c}\text { Sequence of Active } \\
\text { Oligomer }\end{array}$ & Reference \\
\hline A. baumannii & $\begin{array}{l}\text { Resistance to } \\
\text { aminoglycosides }\end{array}$ & $a a c\left(6^{\prime}\right)-I b$ & $\begin{array}{l}\mathrm{BNA}^{\mathrm{NC}} / \mathrm{DNA} \\
\text { conjugated to } \\
(\mathrm{RXR})_{4} \mathrm{XB}^{1}\end{array}$ & $\begin{array}{l}(\mathrm{RXR})_{4} \mathrm{XB}-\mathrm{Cys}-\mathrm{SMCC}-\mathrm{C} 6 \\
\text { amino-cTgctGcgtAacaTc }\end{array}$ & [94] \\
\hline Cell lines & $\begin{array}{c}\text { Myotonic dystrophy } \\
\text { type } 1\end{array}$ & $D M P K^{2}$ & $\begin{array}{l}\mathrm{BNA}^{\mathrm{NC}} / \mathrm{DNA} \\
\text { gapmer }\end{array}$ & CGGAGcggttgtgaaCTGGC & [95] \\
\hline $\begin{array}{l}\text { Murine, human } \\
\text { cell lines, and mice }\end{array}$ & Hypercholesterolemia & $\operatorname{PCSK}^{3}$ & $\begin{array}{l}\mathrm{BNA}^{\mathrm{NC}} / \mathrm{DNA} \\
\text { mixmer }\end{array}$ & CCaggCCTaTgagggTgCCg & [92] \\
\hline Human gene & $\begin{array}{l}\text { Hematologic } \\
\text { malignancies }\end{array}$ & $D N T M 3 A^{4}$ & $\begin{array}{l}\mathrm{BNA}^{\mathrm{NC}} / \mathrm{DNA} \\
\text { mixmers }\end{array}$ & $\begin{array}{l}\text { cgccaAgcgGctcatgtt } \\
\text { cgccAAgcagctcAtgtt } \\
\text { cgccAAgtgGctcAtgtt } \\
\text { cgccaAggggCtcatgtt } \\
\text { cgccAAgctgCtcAtgtt }\end{array}$ & [96] \\
\hline Human gene & $\begin{array}{l}\text { CRISPR-Cas9 } \\
\text { specificity }\end{array}$ & WAS ${ }^{5}$ & $\begin{array}{l}\text { crRNA with BNA }{ }^{\mathrm{NC}} \\
\text { substitutions }\end{array}$ & uggauggagGAAugaggagu & [97] \\
\hline Human gene & $\begin{array}{l}\text { CRISPR-Cas9 } \\
\text { specificity }\end{array}$ & $E^{E X M} 1^{6}$ & $\begin{array}{l}\text { crRNA with BNA }{ }^{\mathrm{NC}} \\
\text { substitutions }\end{array}$ & gaguccgagcaGAAgaagaa & [97] \\
\hline
\end{tabular}

${ }^{1} \mathrm{R}$, arginine; $\mathrm{X}$, 6-aminohexanoic acid; $\mathrm{B}, \beta$-alanine; ${ }^{2}$ Dystrophia myotonica protein kinase; ${ }^{3}$ Proprotein convertase subtilisin/kexin type $9 ;{ }^{4}$ Human DNA methyltransferase $3 \mathrm{~A} ;{ }^{5}$ Gene responsible for Wiskott-Aldrich Syndrome; ${ }^{6}$ Homeobox protein EMX1.

\subsection{Antisense Inhibition of Resistance to Amikacin by a $B N A^{N C}$-Containing Oligomer}

The inhibition of the expression of genes coding for antimicrobial resistance enzymes by diverse antisense mechanisms is the object of intense investigation, as a way to deal with the growing multiresistance problem [4,98-101]. An active antisense molecule could be combined as an adjuvant to the cognate antibiotic to treat resistant infections. The concept of treating resistant infections with combinations of antibiotic/inhibitor of resistance has reached the stage of human use in the case of $\beta$-lactam antibiotics that are administered in combination with $\beta$-lactamase inhibitors $[99,102,103]$. However, combinations of other kinds of antibiotics with inhibitors of resistance are still in experimental 
stages [99,104]. In particular, antisense inhibition of antibiotic resistance genes was explored using oligomers of different natures that interfere with the expression of resistance by different mechanisms [41, $42,78,98,101,105-108]$. The $a a c\left(6^{\prime}\right)$-Ib gene codes for an acetyltransferase responsible for the resistance to amikacin and other aminoglycosides found in the vast majority of AAC(6')-I-producing Gram-negative clinical isolates $[104,109]$. An antisense oligodeoxynucleotide complementary to a duplicated sequence located at the translation initiation location of the $a a c\left(6^{\prime}\right)-I b$ allele found in a clinical Acinetobacter baumannii isolate [110] inhibited translation in vitro [94]. An isosequential 15-residue antisense mixmer, including four $\mathrm{BNA}^{\mathrm{NC}}$ and 11 deoxynucleotide residues, was covalently bound to the permeabilizing peptide ( $R X R)_{4} X B(R$, arginine; $X, 6$-aminohexanoic acid; $B, \beta$-alanine) to generate a compound resistant to nucleases and capable of penetrating the Gram-negative envelope to reach the cytosol. This $\mathrm{BNA}^{\mathrm{NC}}$-containing mixmer, designated CPPBD4, successfully inhibited growth in a liquid culture containing amikacin. Furthermore, a combination of CPPBD4/amikacin reduced the mortality of Galleria mellonella infected with amikacin-resistant $A$. baumannii to levels comparable to those of the uninfected controls [94].

$\mathrm{BNA}^{\mathrm{NC}}$-containing oligomers were also researched as elicitors of RNase P-mediated specific mRNA degradation, an antisense methodology known as external guide sequence (EGS) technology $[4,111]$. In this approach, antisense oligomers, known as EGSs, interact with the target mRNA, forming a structure that is recognized as a substrate by the endogenous RNase P. Then, the enzyme cleaves the mRNA, preventing its translation [5]. Early experiments showed that EGS molecules efficiently reduced the expression of $a a c\left(6^{\prime}\right)-I b$ and levels of resistance to amikacin [108]. Analysis of various nuclease-resistant oligonucleotide analogs indicated that DNA/LNA hybrid oligomers were efficient EGSs that reversed $a a c\left(6^{\prime}\right)$-Ib-mediated resistance to amikacin in a hyperpermeable Escherichia coli strain [42]. Furthermore, conjugation of a selected DNA/LNA hybrid oligomer to the cell permeabilizing peptide $(\mathrm{RXR})_{4} \mathrm{XB}$ reduced the levels of resistance to amikacin of an $a a c\left(6^{\prime}\right)$-Ib-containing Acinetobacter baumannii clinical isolate $[41,78]$. Assessment of isosequential hybrid oligomers containing BNA ${ }^{\text {NC }}$ in the place of the LNA residues showed that they failed to elicit cleavage of the mRNA at levels comparable to those found when testing LNA/DNAs [41].

\subsection{Reversion of Splicing and Reduction of RNA Foci in Myotonic Dystrophy Cells by BNA ${ }^{N C}$ Gapmers}

Myotonic dystrophy type 1 patients may suffer from skeletal muscle weakening and wasting, abnormalities in heart function, cataracts, breathing problems, speech and swallowing disorders, and other impairing symptoms [112]. The molecular basis of this condition is the presence of a CUG repeat expansion within the DMPK gene $3^{\prime}$-untranslated region $[113,114]$. This kind of genetic modification, in which a group of nucleotides that in healthy genes is repeated a variable number of times, exists in an abnormally high number of repeat-characterized diseases, known as microsatellite expansion disorders $[115,116]$. The DMPK gene anomaly causes the mRNA to remain in the nucleus and to form foci structures, resulting in defects in developmentally regulated alternative splicing [117]. Removal of the toxic RNA species using antisense oligomers that induce RNase H cleavage is being intensely researched as a therapeutic strategy. Early work by researchers at IONIS Pharmaceuticals utilizing a gapmer consisting of a short DNA stretch flanked by 2'-O-methoxyethyl residues designed to induce cleavage of the toxic RNA in muscle cells showed encouraging splicing changes, but stopped short of the goals of the trial [95]. The potency of these compounds can be substantially increased by replacing the 2'-O-methoxyethyl analogs with LNA residues [62]. However, antisense LNA-containing gapmers showed high hepatotoxicity [62-64]. The potency and toxicity of $\mathrm{BNA}^{\mathrm{NC}}$-containing gapmers as compared to isosequential LNA-containing gapmers was recently determined [95]. Both compounds were nearly equally efficient in inducing the cleavage of the CUG repeat expansion-containing mRNA in cells transformed with a plasmid designed to express this RNA species. However, comparison of the toxicity of both antisense compounds showed that the LNA-containing gapmer induced an increase in caspases, the apoptosis effector proteins, that was not observed with $\mathrm{BNA}^{\mathrm{NC}}$-containing gapmers [95]. Interestingly, a comparison of the region targeted showed that a gapmer complementary 
to a non-repetitive region of the RNA was more specific in eliciting degradation of the toxic RNA than a gapmer complementary to a segment containing the CUG repeats (Table 1) [95]. These studies indicate that the use of $\mathrm{BNA}^{\mathrm{NC}}$-containing gapmers could open new venues for developing therapies against myotonic dystrophy type 1.

\subsection{Reduction of Cholesterol Levels by BNA ${ }^{N C}$ Mixmers in Hypercholesterolemic Mice}

Proprotein convertase subtilisin/kexin type 9 (PCSK9) plays a role in the maintenance of cholesterol balance [118]. Gain-of-function mutations in this gene are associated with an increase in low-density lipoprotein cholesterol levels (i.e., autosomal dominant hypercholesterolemia), a known risk factor for coronary heart disease [119]. Conversely, loss-of-function mutations are responsible for low plasma low-density lipoprotein cholesterol (LDL-C) levels and reduced incidence of cardiovascular disease [120]. These phenotypes are the consequence of the ability of PCSK9 to interact with the LDL receptor (LDLR). The complex PCSK9-LDLR is transported from the cell's surface to the endosome, where LDLR is degraded [121]. The involvement of PCSK9 in the modulation of LDL-C levels led to attempts to suppress its synthesis or activity that resulted in the development of drugs that have been approved by the FDA [122-126]. In particular, the inhibition of the expression of PCSK9 by antisense oligonucleotide analogs was attempted by several research groups. A 2'-O-methoxyethyl-modified phosphorothioate oligonucleotide analog modestly reduced hepatic PCSK9 mRNA and LDL-C in treated mice [127]. In another study, an LNA-containing gapmer was found to be more efficient at lowering PCSK9 mRNA and LDL-C while increasing LDLR levels [74]. However, LNA-containing gapmers usually show high hepatotoxicity. $\mathrm{BNA}^{\mathrm{NC}}$-containing oligomers could be a better option to design compounds that show high efficiency without the high levels of toxicity observed when the

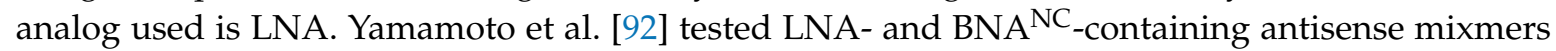
in cultured cells as well as in mice. Cells transfected with mixmers containing one or the other analog showed a dose-dependent reduction of PCSK9 mRNA and increase of LDLR protein levels. Also, the administration of these compounds to atherogenic diet-fed mice biweekly for six weeks resulted in a reduction of PCSK9 mRNA and LDL-C as well as an increase in high-density lipoprotein cholesterol. However, the comparison also showed that the animals treated with the $\mathrm{BNA}^{\mathrm{NC}}$-containing antisense mixmer experienced a reduction of LDL-C after a shorter time and tolerance was higher. These comparative studies identified $\mathrm{BNA}^{\mathrm{NC}}$-containing antisense compounds as better candidates than LNA-containing compounds.

\subsection{Diagnostics of Hematologic Malignancies by the Detection of Somatic Mutations Using BNA ${ }^{N C}$ Mixmers}

DNA methylation, an epigenetic modification, is involved in critical cellular processes, such as replication and transcription. Hypomethylation is correlated to some human cancers [128]. The human DNA methyltransferase 3A (DNMT3A) is a $130 \mathrm{kDa}$ protein that includes three domains, one of which is the $S$-adenosyl methionine-dependent methyltransferase that recognizes and binds DNA to catalyze the transfer of a methyl group to the C5 position of cytosine from S-adenosyl methionine [129]. The nuclear DNMT3A molecules can exist in oligomeric form as dimers, tetramers, and larger structures held by interactions of binding interfaces in the methyltransferase domain [130].

Numerous hematologic malignancies are characterized by the presence of somatic mutations in the DNA methyltransferase 3A (DNMT3A) gene [128]. Mutations on this gene are found in up to $35 \%$ of cases of different myeloid malignancies [131-137]. The detection of mutations in this gene could, therefore, be a component of a group of tests to predict a higher risk of myeloid malignancies [138,139]. Techniques used to detect DNMT3A mutations include DNA sequencing, high-resolution DNA melting, restriction fragment length polymorphism, and denaturing high-performance liquid chromatography [140-144]. A microsphere-based suspension assay that utilizes oligonucleotide analogs, $\mathrm{LNA}$ - or $\mathrm{BNA}^{\mathrm{NC}}$-containing, as probes specific for wild type or mutant alleles was more efficient than direct sequencing [96]. In this study, LNA- or BNA ${ }^{\mathrm{NC}}$-containing oligonucleotides specific for the wild type or four mutations within the codon R882 were coupled 
to fluorescently labeled microspheres, which were used in hybridization assays against DNMT3A amplicons. The utilization of LNA- or $\mathrm{BNA}^{\mathrm{NC}}$-containing analogs facilitated the design of sequences that can discriminate between sequences that differed in a single nucleotide. A comparison of isosequential oligonucleotides that differ in the nature of the analog residues showed that $\mathrm{BNA}^{\mathrm{NC}}$-containing compounds showed the highest sensitivity, as well as specificity. These researchers concluded that BNA $^{\mathrm{NC}}$-containing probes, coupled with fluorescently labeled microspheres, are suitable reagents to detect DNMT3A R888 mutations [96].

\subsection{Incorporation of $B N A^{N C}$ Residues to crRNA as an Enhancer of Cas9 Endonuclease Specificity}

Bacteria have evolved numerous strategies to defend against the presence of foreign genetic material, such as bacteriophage genomes, transposons, and plasmids. They include restriction-modification systems, abortive infections and adsorption blockage, and surface exclusion [145-147]. While these systems are relatively unspecific, the latest discovered defense system, known as "clustered regularly interspaced short palindromic repeats" (CRISPR) is specific and, in a surprisingly analogous mode to vertebrate immune systems, it requires previous exposure to the foreign genetic material to create a memory record that can elicit a quick response in future exposure events [148]. In this system, small guide RNA molecules (crRNAs) guide the sequence-specific cleavage of foreign nucleic acids [149]. However, differences in molecular mechanisms permitted the classification in two classes, class 1 and 2, which depend on a multiprotein complex or a single protein, respectively [149]. Each class is further divided into three types. In particular, the class 2, type II system, which depends on the endonuclease Cas9 (Figure 2), has been developed as a tool for numerous applications, such as the generation of mutants, gene editing, bacterial species identification and typing, antibacterial agents, genome-wide screening in mammalian cells, regulation of gene expression (through the use of dCas9, a derivative that lost the cleavage activity), and others [148-152].

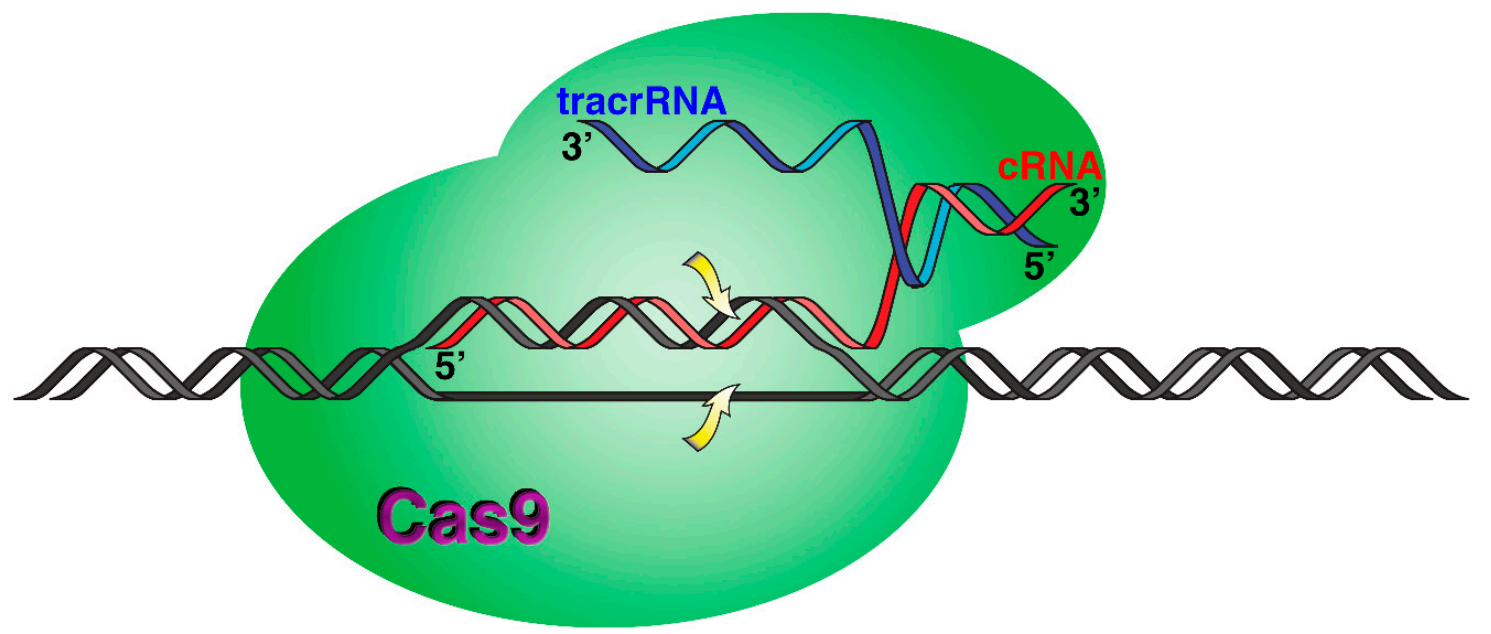

Figure 2. Molecular mechanism of Cas9-mediated digestion of a target DNA. The crRNA and tracrRNA are shown in red and blue, respectively. The arrows indicate the point of cleavage on each target DNA strand.

The Cas9 system relies on two RNA molecules, a crRNA that includes a 20-nucleotide sequence complementary to the target DNA and a trans-acting molecule (tracrRNA) that acts as bridge between the crRNA and the Cas9 endonuclease (Figure 2) [153-155]. Experiments in which the tracrRNA and crRNA are covalently bound, forming a single guide RNA (sgRNA) showed that sgRNAs form viable complexes that result in target cleavage [155]. The Cas9 protein first recognizes protospacer-adjacent motif (PAM) sequences on the target DNA. The role of the PAM sequences is to help in distinguishing self from foreign DNA. Then, a crRNA 20-nucleotides region pairs with the target DNA, forming the multicomponent complex that causes Cas9 double-stranded blunt-ended cleavage $[153,156,157]$. 
The Cas9 system has been widely adapted for gene editing and other applications [152,158-161]. An important consideration in the use of CRISPR-Cas9 as a tool is its specificity. While mutations in the PAM sequences usually interfere with cleavage of the target, mutations within the target sequence that interacts with crRNA (or sgRNA) can be tolerated, permitting digestion at off-target locations [162,163]. Since enhancing the specificity of cleavage is such an important aspect for numerous applications of CRISPR-Cas9, it is not surprising that several approaches have been tested to reduce off-target action $[97,164-166]$. The vast majority of these studies focused on the Cas9 protein $[165,167-170]$. Few others concentrated on modifications to the crRNA [97,170-172]. Cromwell et al. recently took advantage of the enhanced mismatch discrimination of $\mathrm{BNA}^{\mathrm{NC}}$-containing oligomers to design crRNA molecules that elicit cleavage specificity by the cas9 endonuclease [97]. Two crRNA molecules directed to the Wiskott-Aldrich syndrome (WAS) [173] and the homeobox EMX1 [174] genes that are known to also affect off-target sites were used to test the effect of replacing from one to four nucleotides with $\mathrm{BNA}^{\mathrm{NC}}$ residues. In vitro cleavage assays were carried, out using as the target the wild type WAS or EMX1 sequences and five sequences including one, two, or three nucleotide substitutions for each of the genes. These wild type and modified target sequences were incubated in the presence of the endonuclease and crRNA or the isosequential variants, including one to eight BNA ${ }^{\mathrm{NC}}$ residue replacements. While the crRNA molecules directed cleavage of the wild type and all of the modified targets, a crRNA containing BNA ${ }^{\mathrm{NC}}$ residues at positions 12-14 isosequential to the EXM1 crRNA (Table 1) specifically guided cleavage of the wild type target. Similarly, a crRNA containing BNA ${ }^{N C}$ residues at positions 10-12 (Table 1) guided cleavage of the wild type and only one of the modified targets. These results showed a significant enhancement of specificity in vitro when three nucleotides were replaced by $\mathrm{BNA}^{\mathrm{NC}}$ residues. Interestingly, $\mathrm{BNA}^{\mathrm{NC}}$-containing crRNA molecules are compatible with Cas9 variants with improved specificity. Following these encouraging results, experiments to find out if the enhanced specificity observed in the in vitro experiments described above also occurs in vivo were carried out. Cas9-producing U2OS and HeLa cells were transfected with the unmodified and modified crRNA molecules, targeting the WAS and EXM1 genes. The levels of cleavage at the target and off-target sites were consistent with those observed in vitro. This work established that $\mathrm{BNA}^{\mathrm{NC}}$-containing crRNAs could be a venue for improving Cas9 cleavage specificity [97].

\section{Final Remarks}

In the past few years, oligonucleotides have been used for an increasing number of applications in basic science, as well as in clinics and other settings. In particular, applications related to human health include detection and diagnostics of pathologies caused by mutations, silencing of undesirable genes responsible for numerous genetic conditions, or interference with the expression of bacterial or viral genes to fight infection. The increased utilization of these compounds requires the constant search for improvement of their properties. The key aspects that enhance the usability and efficiency of oligonucleotides are their stability, specificity, and bioavailability. While the latter has been dealt with by conjugating the compounds to permeabilizing peptides, using transfecting agents, packaging them into liposomes, and combining them with nanoparticles, stability and specificity were dramatically improved by the substitution of ribonucleotide or deoxyribonucleotide residues with analogs. The success observed by these chemical modifications incentivized the search for new and varying nucleotide analogs that enhanced the resistance to nucleases, specificity, affinity, and activity of the oligomers. The first-generation BNA, known as LNA, has been used for several applications with great success. However, despite the promising results achieved with LNA-containing oligomers, toxicity has been an impediment for their development as therapeutic agents. Conversely, oligonucleotide analogs, including the second generation of BNA compounds, BNA ${ }^{\mathrm{NC}}$, show lower toxicity while preserving and, in some cases, improving on the LNA-containing oligomers. Furthermore, next-generation BNA compounds are in the pipeline, and some are or will soon be available for experimentation $[87,175]$. The success experienced using these nucleotide analogs, and the vigorous efforts to continue developing 
next-generation variants offer promising alternatives to continue the development of new and improved applications of oligonucleotides for research as well as diagnostics and therapeutics.

Author Contributions: All authors contributed equally to writing this article.

Funding: Authors' work cited in this review article was funded by Public Health Service Grant 2R15AI047115 from the National Institutes of Health.

Acknowledgments: Authors' work cited in this review article was funded by Public Health Service Grant 2R15AI047115 from the National Institutes of Health. AZ and ASB are Career members of the Consejo Nacional del Investigaciones Científicas y Tecnológicas (CONICET).

Conflicts of Interest: The authors declare no conflict of interest. The funders had no role in the writing of the manuscript, or in the decision to publish the results.

\section{References}

1. Bennett, C.F.; Swayze, E.E. RNA targeting therapeutics: Molecular mechanisms of antisense oligonucleotides as a therapeutic platform. Annu. Rev. Pharmacol. Toxicol. 2010, 50, 259-293. [CrossRef] [PubMed]

2. Thomason, M.K.; Storz, G. Bacterial antisense RNAs: How many are there, and what are they doing? Annu. Rev. Genet. 2010, 44, 167-188. [CrossRef] [PubMed]

3. Rasmussen, L.C.; Sperling-Petersen, H.U.; Mortensen, K.K. Hitting bacteria at the heart of the central dogma: Sequence-specific inhibition. Microb. Cell Fact. 2007, 6, 24. [CrossRef]

4. Davies-Sala, C.; Soler-Bistue, A.; Bonomo, R.A.; Zorreguieta, A.; Tolmasky, M.E. External guide sequence technology: A path to development of novel antimicrobial therapeutics. Ann. N.Y. Acad. Sci. 2015, 1354, 98-110. [CrossRef] [PubMed]

5. Forster, A.C.; Altman, S. External guide sequences for an RNA enzyme. Science 1990, 249, 783-786. [CrossRef] [PubMed]

6. Burnett, J.C.; Rossi, J.J. RNA-based therapeutics: Current progress and future prospects. Chem. Biol. 2012, 19, 60-71. [CrossRef] [PubMed]

7. Li, M.J.; Kim, J.; Li, S.; Zaia, J.; Yee, J.K.; Anderson, J.; Akkina, R.; Rossi, J.J. Long-term inhibition of HIV-1 infection in primary hematopoietic cells by lentiviral vector delivery of a triple combination of anti-HIV shRNA, anti-CCR5 ribozyme, and a nucleolar-localizing TAR decoy. Mol. Ther. 2005, 12, 900-909. [CrossRef]

8. Ni, X.; Castanares, M.; Mukherjee, A.; Lupold, S.E. Nucleic acid aptamers: Clinical applications and promising new horizons. Curr. Med. Chem. 2011, 18, 4206-4214. [CrossRef]

9. Ellington, A.D.; Szostak, J.W. In vitro selection of RNA molecules that bind specific ligands. Nature 1990, 346, 818-822. [CrossRef]

10. Crooke, S.T.; Witztum, J.L.; Bennett, C.F.; Baker, B.F. RNA-Targeted Therapeutics. Cell Metab. 2018, 27, 714-739. [CrossRef]

11. Setten, R.L.; Rossi, J.J.; Han, S.P. The current state and future directions of RNAi-based therapeutics. Nat. Rev. Drug Discov. 2019, 18, 421-446. [CrossRef] [PubMed]

12. Caplen, N.J.; Parrish, S.; Imani, F.; Fire, A.; Morgan, R.A. Specific inhibition of gene expression by small double-stranded RNAs in invertebrate and vertebrate systems. Proc. Natl. Acad. Sci. USA 2001, 98, 9742-9747. [CrossRef] [PubMed]

13. van Rooij, E.; Kauppinen, S. Development of microRNA therapeutics is coming of age. EMBO Mol. Med. 2014, 6, 851-864. [CrossRef] [PubMed]

14. van Rooij, E.; Sutherland, L.B.; Qi, X.; Richardson, J.A.; Hill, J.; Olson, E.N. Control of stress-dependent cardiac growth and gene expression by a microRNA. Science 2007, 316, 575-579. [CrossRef]

15. Eckstein, F. Nucleoside phosphorothioates. J. Am. Chem. Soc. 1966, 88, 4292-4294. [CrossRef]

16. Eckstein, F. Phosphorothioates, essential components of therapeutic oligonucleotides. Nucleic Acid Ther. 2014, 24, 374-387. [CrossRef] [PubMed]

17. Ts'o, P.O.; Miller, P.S.; Aurelian, L.; Murakami, A.; Agris, C.; Blake, K.R.; Lin, S.B.; Lee, B.L.; Smith, C.C. An approach to chemotherapy based on base sequence information and nucleic acid chemistry. Ann. N.Y. Acad. Sci. 1987, 507, 220-241. [CrossRef]

18. Geary, R.S.; Henry, S.P.; Grillone, L.R. Fomivirsen: Clinical pharmacology and potential drug interactions. Clin. Pharmacokinet. 2002, 41, 255-260. [CrossRef] 
19. Mellbye, B.L.; Weller, D.D.; Hassinger, J.N.; Reeves, M.D.; Lovejoy, C.E.; Iversen, P.L.; Geller, B.L. Cationic phosphorodiamidate morpholino oligomers efficiently prevent growth of Escherichia coli in vitro and in vivo. J. Antimicrob. Chemother. 2010, 65, 98-106. [CrossRef]

20. Gupta, A.; Mishra, A.; Puri, N. Peptide nucleic acids: Advanced tools for biomedical applications. J. Biotechnol. 2017, 259, 148-159. [CrossRef]

21. Nielsen, P.E. Peptide nucleic acids (PNA) in chemical biology and drug discovery. Chem. Biodivers. 2010, 7 , 786-804. [CrossRef]

22. Le, B.T.; Hornum, M.; Sharma, P.K.; Nielsen, P.; Veedu, R.N. Nucleobase-modified antisense oligonucleotides containing 5-(phenyltriazol)-2'-deoxyuridine nucleotides induce exon-skipping in vitro. RSC Adv. 2017, 7, 54542-54545. [CrossRef]

23. Meng, M.; Ducho, C. Oligonucleotide analogues with cationic backbone linkages. Beilstein J. Org. Chem. 2018, 14, 1293-1308. [CrossRef]

24. Petersen, M.; Wengel, J. LNA: A versatile tool for therapeutics and genomics. Trends Biotechnol. 2003, 21, 74-81. [CrossRef]

25. Sharma, V.K.; Rungta, P.; Prasad, A.K. Nucleic acid therapeutics: Basic concepts and recent developments. RSC Adv. 2014, 4, 16618-16631. [CrossRef]

26. Sully, E.K.; Geller, B.L. Antisense antimicrobial therapeutics. Curr. Opin. Microbiol. 2016, 33, 47-55. [CrossRef]

27. Iversen, P.L. Phosphorodiamidate morpholino oligomers: Favorable properties for sequence-specific gene inactivation. Curr. Opin. Mol. Ther. 2001, 3, 235-238.

28. Miyashita, K.; Rahman, S.M.; Seki, S.; Obika, S.; Imanishi, T. N-Methyl substituted 2' ,4' - BNANC: A highly nuclease-resistant nucleic acid analogue with high-affinity RNA selective hybridization. Chem. Commun. 2007, 3765-3767. [CrossRef]

29. Rahman, S.M.; Seki, S.; Obika, S.; Yoshikawa, H.; Miyashita, K.; Imanishi, T. Design, synthesis, and properties of 2', 4'-BNA(NC): A bridged nucleic acid analogue. J. Am. Chem. Soc. 2008, 130, 4886-4896. [CrossRef]

30. Rahman, S.M.; Seki, S.; Utsuki, K.; Obika, S.; Miyashita, K.; Imanishi, T. 2', 4'-BNA(NC): A novel bridged nucleic acid analogue with excellent hybridizing and nuclease resistance profiles. Nucleosides Nucleotides Nucleic Acids 2007, 26, 1625-1628. [CrossRef]

31. Fujisaka, A.; Hari, Y.; Takuma, H.; Rahman, S.M.A.; Yoshikawa, H.; Pang, J.; Imanishi, T.; Obika, S. Effective syntheses of $2^{\prime}, 4^{\prime}$-BNA(NC) monomers bearing adenine, guanine, thymine, and 5-methylcytosine, and the properties of oligonucleotides fully modified with $2^{\prime}, 4^{\prime}$-BNA(NC). Bioorg. Med. Chem. 2019, 27, 1728-1741. [CrossRef]

32. Koshkin, A.A.; Nielsen, P.; Meldgaard, M.; Rajwanshi, V.K.; Singh, S.K.; Wengel, J. LNA (locked nucleic acid): An RNA mimic forming exceedingly stable LNA: LNA duplexes. J. Am. Chem. Soc. 1998, 120, 13252-13253. [CrossRef]

33. Koshkin, A.A.; Rajwanshi, V.K.; Wengel, J. Novel convenient syntheses of LNA [2.2.1] bicyclo nucleosides. Tetrahedron Lett. 1998, 39, 4381-4384. [CrossRef]

34. Koshkin, A.A.; Singh, S.K.; Nielsen, P.; Rajwanshi, V.K.; Kumar, R.; Meldgaard, M.; Olsen, C.E.; Wengel, J. LNA (Locked Nucleic Acids): Synthesis of the adenine, cytosine, guanine, 5-methylcytosine, thymine and uracil bicyclonucleoside monomers, oligomerisation, and unprecedented nucleic acid recognition. Tetrahedron 1998, 54, 3607-3630. [CrossRef]

35. Singh, S.K.; Kumar, R.; Wengel, J. Synthesis of novel bicyclo [2.2.1] ribonucleosides: 2' -amino- and 2' -thio-LNA monomeric nucleosides. J. Org. Chem. 1998, 63, 6078-6079. [CrossRef]

36. Wang, G.; Gunic, E.; Girardet, J.L.; Stoisavljevic, V. Conformationally locked nucleosides. Synthesis and hybridization properties of oligodeoxynucleotides containing 2',4'-C-bridged 2'-deoxynucleosides. Bioorg. Med. Chem. Lett. 1999, 9, 1147-1150. [CrossRef]

37. Obika, S.; Nanbu, D.; Hari, Y.; Andoh, J.; Morio, K.; Doi, T.; Imanishi, T. Stability and structural features of the duplexes containing nucleoside analogues with a fixed N-type conformation, 2'-O,4'-C-methyleneribonucleosides. Tetrahedron Lett. 1998, 39, 5401-5404. [CrossRef]

38. Veedu, R.N.; Wengel, J. Locked nucleic acids: Promising nucleic acid analogs for therapeutic applications. Chem. Biodivers. 2010, 7, 536-542. [CrossRef]

39. Bhattacharyya, J.; Maiti, S.; Muhuri, S.; Nakano, S.; Miyoshi, D.; Sugimoto, N. Effect of locked nucleic acid modifications on the thermal stability of noncanonical DNA structure. Biochemistry 2011, 50, 7414-7425. [CrossRef] 
40. Braasch, D.A.; Corey, D.R. Locked nucleic acid (LNA): Fine-tuning the recognition of DNA and RNA. Chem. Biol. 2001, 8, 1-7. [CrossRef]

41. Jackson, A.; Jani, S.; Sala, C.D.; Soler-Bistue, A.J.; Zorreguieta, A.; Tolmasky, M.E. Assessment of configurations and chemistries of bridged nucleic acids-containing oligomers as external guide sequences: A methodology for inhibition of expression of antibiotic resistance genes. Biol. Methods Protoc. 2016, 1, bpw001. [CrossRef]

42. Soler Bistue, A.J.; Martin, F.A.; Vozza, N.; Ha, H.; Joaquin, J.C.; Zorreguieta, A.; Tolmasky, M.E. Inhibition of $a a c\left(6^{\prime}\right)$-Ib-mediated amikacin resistance by nuclease-resistant external guide sequences in bacteria. Proc. Natl. Acad. Sci. USA 2009, 106, 13230-13235. [CrossRef]

43. Arzumanov, A.; Stetsenko, D.A.; Malakhov, A.D.; Reichelt, S.; Sorensen, M.D.; Babu, B.R.; Wengel, J.; Gait, M.J. A structure-activity study of the inhibition of HIV-1 Tat-dependent trans-activation by mixmer 2'-O-methyl oligoribonucleotides containing locked nucleic acid (LNA), alpha-L-LNA, or 2'-thio-LNA residues. Oligonucleotides 2003, 13, 435-453. [CrossRef]

44. Arzumanov, A.; Walsh, A.P.; Rajwanshi, V.K.; Kumar, R.; Wengel, J.; Gait, M.J. Inhibition of HIV-1 Tat-dependent trans activation by steric block chimeric 2'-O-methyl/LNA oligoribonucleotides. Biochemistry 2001, 40, 14645-14654. [CrossRef]

45. Singh, S.K.; Wengel, J. Universality of LNA-mediated high-affinity nucleic acid recognition. Chem. Commun. 1998, 1247-1248. [CrossRef]

46. Stenvang, J.; Silahtaroglu, A.N.; Lindow, M.; Elmen, J.; Kauppinen, S. The utility of LNA in microRNA-based cancer diagnostics and therapeutics. Semin. Cancer Biol. 2008, 18, 89-102. [CrossRef]

47. Mouritzen, P.; Nielsen, A.T.; Pfundheller, H.M.; Choleva, Y.; Kongsbak, L.; Moller, S. Single nucleotide polymorphism genotyping using locked nucleic acid (LNA). Expert Rev. Mol. Diagn. 2003, 3, 27-38. [CrossRef]

48. Jakobsen, U.; Vogel, S. Mismatch discrimination of lipidated DNA and LNA-probes (LiNAs) in hybridization-controlled liposome assembly. Org. Biomol. Chem. 2016, 14, 6985-6995. [CrossRef]

49. Simon, L.; Probst, A.V. High-affinity LNA-DNA mixmer probes for detection of chromosome-specific polymorphisms of 5S rDNA repeats in Arabidopsis thaliana. Methods Mol. Biol. 2018, 1675, 481-491.

50. Ikenaga, M.; Katsuragi, S.; Handa, Y.; Katsumata, H.; Chishaki, N.; Kawauchi, T.; Sakai, M. Improvements in bacterial primers to enhance selective SSU rRNA gene amplification of plant-associated bacteria by applying the LNA oligonucleotide-PCR clamping technique. Microbes Environ. 2018, 33, 340-344. [CrossRef]

51. Levin, J.D.; Fiala, D.; Samala, M.F.; Kahn, J.D.; Peterson, R.J. Position-dependent effects of locked nucleic acid (LNA) on DNA sequencing and PCR primers. Nucleic Acids Res. 2006, 34, e142. [CrossRef]

52. Pakpour, N.; Cheung, K.W.; Souvannaseng, L.; Concordet, J.P.; Luckhart, S. Transfection and mutagenesis of target genes in mosquito cells by locked nucleic acid-modified oligonucleotides. J. Vis. Exp. 2010, 2355. [CrossRef]

53. van Ravesteyn, T.W.; Dekker, M.; Fish, A.; Sixma, T.K.; Wolters, A.; Dekker, R.J.; Te Riele, H.P. LNA modification of single-stranded DNA oligonucleotides allows subtle gene modification in mismatch-repair-proficient cells. Proc. Natl. Acad. Sci. USA 2016, 113, 4122-4127. [CrossRef]

54. Parekh-Olmedo, H.; Drury, M.; Kmiec, E.B. Targeted nucleotide exchange in Saccharomyces cerevisiae directed by short oligonucleotides containing locked nucleic acids. Chem. Biol. 2002, 9, 1073-1084. [CrossRef]

55. Wojtkowiak-Szlachcic, A.; Taylor, K.; Stepniak-Konieczna, E.; Sznajder, L.J.; Mykowska, A.; Sroka, J.; Thornton, C.A.; Sobczak, K. Short antisense-locked nucleic acids (all-LNAs) correct alternative splicing abnormalities in myotonic dystrophy. Nucleic Acids Res. 2015, 43, 3318-3331. [CrossRef]

56. Elmen, J.; Lindow, M.; Schutz, S.; Lawrence, M.; Petri, A.; Obad, S.; Lindholm, M.; Hedtjarn, M.; Hansen, H.F.; Berger, U.; et al. LNA-mediated microRNA silencing in non-human primates. Nature 2008, 452, 896-899. [CrossRef]

57. Janssen, H.L.; Reesink, H.W.; Lawitz, E.J.; Zeuzem, S.; Rodriguez-Torres, M.; Patel, K.; van der Meer, A.J.; Patick, A.K.; Chen, A.; Zhou, Y.; et al. Treatment of HCV infection by targeting microRNA. N. Engl. J. Med. 2013, 368, 1685-1694. [CrossRef]

58. van der Ree, M.H.; de Vree, J.M.; Stelma, F.; Willemse, S.; van der Valk, M.; Rietdijk, S.; Molenkamp, R.; Schinkel, J.; van Nuenen, A.C.; Beuers, U.; et al. Safety, tolerability, and antiviral effect of RG-101 in patients with chronic hepatitis C: A phase 1B, double-blind, randomised controlled trial. Lancet 2017, 389, 709-717. [CrossRef] 
59. van der Ree, M.H.; van der Meer, A.J.; de Bruijne, J.; Maan, R.; van Vliet, A.; Welzel, T.M.; Zeuzem, S.; Lawitz, E.J.; Rodriguez-Torres, M.; Kupcova, V.; et al. Long-term safety and efficacy of microRNA-targeted therapy in chronic hepatitis C patients. Antivir. Res. 2014, 111, 53-59. [CrossRef]

60. Guerard, M.; Andreas, Z.; Erich, K.; Christine, M.; Martina, M.B.; Christian, W.; Franz, S.; Thomas, S.; Yann, T. Locked nucleic acid (LNA): Based single-stranded oligonucleotides are not genotoxic. Environ. Mol. Mutagen. 2017, 58, 112-121. [CrossRef]

61. Bianchini, D.; Omlin, A.; Pezaro, C.; Lorente, D.; Ferraldeschi, R.; Mukherji, D.; Crespo, M.; Figueiredo, I.; Miranda, S.; Riisnaes, R.; et al. First-in-human Phase I study of EZN-4176, a locked nucleic acid antisense oligonucleotide to exon 4 of the androgen receptor mRNA in patients with castration-resistant prostate cancer. Br. J. Cancer 2013, 109, 2579-2586. [CrossRef]

62. Swayze, E.E.; Siwkowski, A.M.; Wancewicz, E.V.; Migawa, M.T.; Wyrzykiewicz, T.K.; Hung, G.; Monia, B.P.; Bennett, C.F. Antisense oligonucleotides containing locked nucleic acid improve potency but cause significant hepatotoxicity in animals. Nucleic Acids Res. 2007, 35, 687-700. [CrossRef]

63. Kakiuchi-Kiyota, S.; Koza-Taylor, P.H.; Mantena, S.R.; Nelms, L.F.; Enayetallah, A.E.; Hollingshead, B.D.; Burdick, A.D.; Reed, L.A.; Warneke, J.A.; Whiteley, L.O.; et al. Comparison of hepatic transcription profiles of locked ribonucleic acid antisense oligonucleotides: Evidence of distinct pathways contributing to non-target mediated toxicity in mice. Toxicol. Sci. 2014, 138, 234-248. [CrossRef]

64. Kasuya, T.; Hori, S.; Watanabe, A.; Nakajima, M.; Gahara, Y.; Rokushima, M.; Yanagimoto, T.; Kugimiya, A. Ribonuclease H1-dependent hepatotoxicity caused by locked nucleic acid-modified gapmer antisense oligonucleotides. Sci. Rep. 2016, 6, 30377. [CrossRef]

65. Stein, C.A.; Hansen, J.B.; Lai, J.; Wu, S.; Voskresenskiy, A.; Hog, A.; Worm, J.; Hedtjarn, M.; Souleimanian, N.; Miller, P.; et al. Efficient gene silencing by delivery of locked nucleic acid antisense oligonucleotides, unassisted by transfection reagents. Nucleic Acids Res. 2010, 38, e3. [CrossRef]

66. Traglia, G.M.; Sala, C.D.; Fuxman Bass, J.I.; Soler-Bistue, A.J.; Zorreguieta, A.; Ramirez, M.S.; Tolmasky, M.E. Internalization of locked nucleic acids/DNA hybrid oligomers into Escherichia coli. Biores. Open Access 2012, 1, 260-263. [CrossRef]

67. Soifer, H.S.; Koch, T.; Lai, J.; Hansen, B.; Hoeg, A.; Oerum, H.; Stein, C.A. Silencing of gene expression by gymnotic delivery of antisense oligonucleotides. Methods Mol. Biol. 2012, 815, 333-346.

68. Mettlen, M.; Pucadyil, T.; Ramachandran, R.; Schmid, S.L. Dissecting dynamin's role in clathrin-mediated endocytosis. Biochem. Soc. Trans. 2009, 37, 1022-1026. [CrossRef]

69. Lajoie, P.; Nabi, I.R. Lipid rafts, caveolae, and their endocytosis. Int. Rev. Cell Mol. Biol. 2010, 282, $135-163$.

70. Howes, M.T.; Mayor, S.; Parton, R.G. Molecules, mechanisms, and cellular roles of clathrin-independent endocytosis. Curr. Opin. Cell Biol. 2010, 22, 519-527. [CrossRef]

71. Juliano, R.L. The delivery of therapeutic oligonucleotides. Nucleic Acids Res. 2016, 44, 6518-6548. [CrossRef]

72. Johannes, L.; Lucchino, M. Current challenges in delivery and cytosolic translocation of therapeutic RNAs. Nucleic Acid Ther. 2018, 28, 178-193. [CrossRef]

73. Fabani, M.M.; Gait, M.J. miR-122 targeting with LNA/2'-O-methyl oligonucleotide mixmers, peptide nucleic acids (PNA), and PNA-peptide conjugates. RNA 2008, 14, 336-346. [CrossRef]

74. Gupta, N.; Fisker, N.; Asselin, M.C.; Lindholm, M.; Rosenbohm, C.; Orum, H.; Elmen, J.; Seidah, N.G.; Straarup, E.M. A locked nucleic acid antisense oligonucleotide (LNA) silences PCSK9 and enhances LDLR expression in vitro and in vivo. PLoS ONE 2010, 5, e10682. [CrossRef]

75. Beane, R.; Gabillet, S.; Montaillier, C.; Arar, K.; Corey, D.R. Recognition of chromosomal DNA inside cells by locked nucleic acids. Biochemistry 2008, 47, 13147-13149. [CrossRef]

76. Grunweller, A.; Wyszko, E.; Bieber, B.; Jahnel, R.; Erdmann, V.A.; Kurreck, J. Comparison of different antisense strategies in mammalian cells using locked nucleic acids, 2'-O-methyl RNA, phosphorothioates and small interfering RNA. Nucleic Acids Res. 2003, 31, 3185-3193. [CrossRef]

77. Turner, J.J.; Jones, S.; Fabani, M.M.; Ivanova, G.; Arzumanov, A.A.; Gait, M.J. RNA targeting with peptide conjugates of oligonucleotides, siRNA and PNA. Blood Cells Mol. Dis. 2007, 38, 1-7. [CrossRef]

78. Jani, S.; Jackson, A.; Davies-Sala, C.; Chiem, K.; Soler-Bistue, A.; Zorreguieta, A.; Tolmasky, M.E. Assessment of external guide sequences' (EGS) efficiency as inducers of RNase P-mediated cleavage of mRNA target molecules. Methods Mol. Biol. 2018, 1737, 89-98.

79. Yin, H.; Wang, H.; Li, Z.; Shu, D.; Guo, P. RNA micelles for systemic delivery of anti-miRNA for cancer targeting and inhibition without ligand. ACS Nano 2018, 13, 706-717. [CrossRef] 
80. Elmen, J.; Zhang, H.Y.; Zuber, B.; Ljungberg, K.; Wahren, B.; Wahlestedt, C.; Liang, Z. Locked nucleic acid containing antisense oligonucleotides enhance inhibition of HIV-1 genome dimerization and inhibit virus replication. FEBS Lett. 2004, 578, 285-290. [CrossRef]

81. Kurreck, J.; Wyszko, E.; Gillen, C.; Erdmann, V.A. Design of antisense oligonucleotides stabilized by locked nucleic acids. Nucleic Acids Res. 2002, 30, 1911-1918. [CrossRef]

82. Kaur, H.; Babu, B.R.; Maiti, S. Perspectives on chemistry and therapeutic applications of Locked Nucleic Acid (LNA). Chem. Rev. 2007, 107, 4672-4697. [CrossRef]

83. Hagedorn, P.H.; Persson, R.; Funder, E.D.; Albaek, N.; Diemer, S.L.; Hansen, D.J.; Moller, M.R.; Papargyri, N.; Christiansen, H.; Hansen, B.R.; et al. Locked nucleic acid: Modality, diversity, and drug discovery. Drug Discov. Today 2018, 23, 101-114. [CrossRef]

84. Grunweller, A.; Hartmann, R.K. Locked nucleic acid oligonucleotides: The next generation of antisense agents? Biodrugs 2007, 21, 235-243. [CrossRef]

85. Sadewasser, A.; Dietzel, E.; Michel, S.; Kluver, M.; Helfer, M.; Thelemann, T.; Klar, R.; Eickmann, M.; Becker, S.; Jaschinski, F. Anti-Niemann Pick C1 single-stranded oligonucleotides with locked nucleic acids potently reduce ebola virus infection in vitro. Mol. Ther. Nucleic Acids 2019, 16, 686-697. [CrossRef]

86. Hillebrand, F.; Ostermann, P.N.; Muller, L.; Degrandi, D.; Erkelenz, S.; Widera, M.; Pfeffer, K.; Schaal, H. Gymnotic delivery of LNA mixmers targeting viral SREs induces HIV-1 mRNA degradation. Int. J. Mol. Sci. 2019, 20, 1088. [CrossRef]

87. Kim, S.; Linse, K.; Retes, P.; Castro, P.; Castro, M. Bridged nucleic acids (BNAs) as molecular tools. J. Biochem. Mol. Biol. Res. 2015, 1, 67-71.

88. Morita, K.; Koizumi, M. Synthesis of ENA nucleotides and ENA oligonucleotides. Curr. Protoc. Nucleic Acid Chem. 2018, 72, 4.79.01-4.79.21. [CrossRef]

89. Mitsuoka, Y.; Kodama, T.; Ohnishi, R.; Hari, Y.; Imanishi, T.; Obika, S. A bridged nucleic acid, 2' , 4'-BNA COC: Synthesis of fully modified oligonucleotides bearing thymine, 5-methylcytosine, adenine and guanine $2^{\prime}, 4^{\prime}$-BNA COC monomers and RNA-selective nucleic-acid recognition. Nucleic Acids Res. 2009, 37, 1225-1238. [CrossRef]

90. Kotkowiak, W.; Wengel, J.; Scotton, C.J.; Pasternak, A. Improved RE31 analogues containing modified nucleic acid monomers: Thermodynamic, structural, and biological effects. J. Med. Chem. 2019, 62, 2499-2507. [CrossRef]

91. Ferino, A.; Miglietta, G.; Picco, R.; Vogel, S.; Wengel, J.; Xodo, L.E. MicroRNA therapeutics: Design of single-stranded miR-216b mimics to target KRAS in pancreatic cancer cells. RNA Biol. 2018, 15, 1273-1285. [CrossRef]

92. Yamamoto, T.; Harada-Shiba, M.; Nakatani, M.; Wada, S.; Yasuhara, H.; Narukawa, K.; Sasaki, K.; Shibata, M.A.; Torigoe, H.; Yamaoka, T.; et al. Cholesterol-lowering action of BNA-based antisense oligonucleotides targeting PCSK9 in atherogenic diet-induced hypercholesterolemic mice. Mol. Ther. Nucleic Acids 2012, 1, e22. [CrossRef]

93. Rahman, S.M.; Seki, S.; Obika, S.; Haitani, S.; Miyashita, K.; Imanishi, T. Highly stable pyrimidine-motif triplex formation at physiological $\mathrm{pH}$ values by a bridged nucleic acid analogue. Angew. Chem. Int. Ed. Engl. 2007, 46, 4306-4309. [CrossRef]

94. Lopez, C.; Arivett, B.A.; Actis, L.A.; Tolmasky, M.E. Inhibition of AAC(6')-Ib-mediated resistance to amikacin in Acinetobacter baumannii by an antisense peptide-conjugated $2^{\prime}, 4^{\prime}$-bridged nucleic acid-NC-DNA hybrid oligomer. Antimicrob. Agents Chemother. 2015, 59, 5798-5803. [CrossRef]

95. Manning, K.S.; Rao, A.N.; Castro, M.; Cooper, T.A. BNA(NC) gapmers revert splicing and reduce RNA foci with low toxicity in myotonic dystrophy cells. ACS Chem. Biol. 2017, 12, 2503-2509. [CrossRef]

96. Shivarov, V.; Ivanova, M.; Naumova, E. Rapid detection of DNMT3A R882 mutations in hematologic malignancies using a novel bead-based suspension assay with BNA(NC) probes. PLoS ONE 2014, 9, e99769. [CrossRef]

97. Cromwell, C.R.; Sung, K.; Park, J.; Krysler, A.R.; Jovel, J.; Kim, S.K.; Hubbard, B.P. Incorporation of bridged nucleic acids into CRISPR RNAs improves Cas9 endonuclease specificity. Nat. Commun. 2018, 9, 1448. [CrossRef]

98. Good, L.; Nielsen, P.E. Antisense inhibition of gene expression in bacteria by PNA targeted to mRNA. Nat. Biotechnol. 1998, 16, 355-358. [CrossRef] 
99. Tolmasky, M.E. Strategies to prolong the useful life of existing antibiotics and help overcoming the antibiotic resistance crisis. In Frontiers in Clinical Drug Research-Anti Infectives; Atta-ur-Rhaman, Ed.; Bentham Books: Sharjah, United Arab Emirates, 2017; Volume 1, pp. 1-27.

100. Guerrier-Takada, C.; Salavati, R.; Altman, S. Phenotypic conversion of drug-resistant bacteria to drug sensitivity. Proc. Natl. Acad. Sci. USA 1997, 94, 8468-8472. [CrossRef]

101. Ayhan, D.H.; Tamer, Y.T.; Akbar, M.; Bailey, S.M.; Wong, M.; Daly, S.M.; Greenberg, D.E.; Toprak, E. Sequence-specific targeting of bacterial resistance genes increases antibiotic efficacy. PLoS Biol. 2016, 14, e1002552. [CrossRef]

102. Ju, L.C.; Cheng, Z.; Fast, W.; Bonomo, R.A.; Crowder, M.W. The continuing challenge of metallo-beta-lactamase inhibition: Mechanism matters. Trends Pharmacol. Sci. 2018, 39, 635-647. [CrossRef]

103. van den Akker, F.; Bonomo, R.A. Exploring additional dimensions of complexity in inhibitor design for serine beta-lactamases: Mechanistic and intra- and inter-molecular chemistry approaches. Front. Microbiol. 2018, 9, 622. [CrossRef]

104. Ramirez, M.S.; Tolmasky, M.E. Aminoglycoside modifying enzymes. Drug Resist. Updates 2010, 13, $151-171$. [CrossRef]

105. Meng, J.; He, G.; Wang, H.; Jia, M.; Ma, X.; Da, F.; Wang, N.; Hou, Z.; Xue, X.; Li, M.; et al. Reversion of antibiotic resistance by inhibiting mecA in clinical methicillin-resistant Staphylococci by antisense phosphorothioate oligonucleotide. J. Antibiot. (Tokyo) 2015, 68, 158-164. [CrossRef]

106. Sully, E.K.; Geller, B.L.; Li, L.; Moody, C.M.; Bailey, S.M.; Moore, A.L.; Wong, M.; Nordmann, P.; Daly, S.M.; Sturge, C.R.; et al. Peptide-conjugated phosphorodiamidate morpholino oligomer (PPMO) restores carbapenem susceptibility to NDM-1-positive pathogens in vitro and in vivo. J. Antimicrob. Chemother. 2016, 72, 782-790.

107. Sarno, R.; Ha, H.; Weinsetel, N.; Tolmasky, M.E. Inhibition of aminoglycoside $6^{\prime}$-N-acetyltransferase type Ib-mediated amikacin resistance by antisense oligodeoxynucleotides. Antimicrob. Agents Chemother. 2003, 47, 3296-3304. [CrossRef]

108. Soler Bistue, A.J.; Ha, H.; Sarno, R.; Don, M.; Zorreguieta, A.; Tolmasky, M.E. External guide sequences targeting the $a a c\left(6^{\prime}\right)-I b$ mRNA induce inhibition of amikacin resistance. Antimicrob. Agents Chemother. 2007, 51, 1918-1925. [CrossRef]

109. Vakulenko, S.B.; Mobashery, S. Versatility of aminoglycosides and prospects for their future. Clin. Microbiol. Rev. 2003, 16, 430-450. [CrossRef]

110. Arivett, B.A.; Fiester, S.E.; Ream, D.C.; Centron, D.; Ramirez, M.S.; Tolmasky, M.E.; Actis, L.A. Draft genome of the multidrug-resistant Acinetobacter baumannii strain A155 clinical isolate. Genome Announc. 2015, 3, e00212-15. [CrossRef]

111. Lundblad, E.W.; Altman, S. Inhibition of gene expression by RNase P. New Biotechnol. 2010, 27, $212-221$. [CrossRef]

112. Bird, T.D. Myotonic Dystrophy Type 1. In GeneReviews; Adam, M.P., Ardinger, H.H., Pagon, R.A., Wallace, S.E., Bean, L.J.H., Stephens, K., Amemiya, A., Eds.; University of Washington: Seattle, WA, USA, 1993.

113. Brook, J.D.; McCurrach, M.E.; Harley, H.G.; Buckler, A.J.; Church, D.; Aburatani, H.; Hunter, K.; Stanton, V.P.; Thirion, J.P.; Hudson, T.; et al. Molecular basis of myotonic dystrophy: Expansion of a trinucleotide (CTG) repeat at the 3' end of a transcript encoding a protein kinase family member. Cell 1992, 68, 799-808. [CrossRef]

114. Mahadevan, M.; Tsilfidis, C.; Sabourin, L.; Shutler, G.; Amemiya, C.; Jansen, G.; Neville, C.; Narang, M.; Barcelo, J.; O'Hoy, K.; et al. Myotonic dystrophy mutation: An unstable CTG repeat in the 3' untranslated region of the gene. Science 1992, 255, 1253-1255. [CrossRef]

115. Brouwer, J.R.; Willemsen, R.; Oostra, B.A. Microsatellite repeat instability and neurological disease. Bioessays 2009, 31, 71-83. [CrossRef]

116. Lee, J.E.; Cooper, T.A. Pathogenic mechanisms of myotonic dystrophy. Biochem. Soc. Trans. 2009, 37, 1281-1286. [CrossRef]

117. Thornton, C.A. Myotonic dystrophy. Neurol. Clin. 2014, 32, 705-719. [CrossRef]

118. Blanchard, V.; Khantalin, I.; Ramin-Mangata, S.; Chemello, K.; Nativel, B.; Lambert, G. PCSK9: From biology to clinical applications. Pathology 2019, 51, 177-183. [CrossRef]

119. Abifadel, M.; Varret, M.; Rabes, J.P.; Allard, D.; Ouguerram, K.; Devillers, M.; Cruaud, C.; Benjannet, S.; Wickham, L.; Erlich, D.; et al. Mutations in PCSK9 cause autosomal dominant hypercholesterolemia. Nat. Genet. 2003, 34, 154-156. [CrossRef] 
120. Hallman, D.M.; Srinivasan, S.R.; Chen, W.; Boerwinkle, E.; Berenson, G.S. Relation of PCSK9 mutations to serum low-density lipoprotein cholesterol in childhood and adulthood (from The Bogalusa Heart Study). Am. J. Cardiol. 2007, 100, 69-72. [CrossRef]

121. Lambert, G.; Charlton, F.; Rye, K.A.; Piper, D.E. Molecular basis of PCSK9 function. Atherosclerosis 2009, 203, 1-7. [CrossRef]

122. Cameron, J.; Ranheim, T.; Kulseth, M.A.; Leren, T.P.; Berge, K.E. Berberine decreases PCSK9 expression in HepG2 cells. Atherosclerosis 2008, 201, 266-273. [CrossRef]

123. Kong, W.J.; Wei, J.; Zuo, Z.Y.; Wang, Y.M.; Song, D.Q.; You, X.F.; Zhao, L.X.; Pan, H.N.; Jiang, J.D. Combination of simvastatin with berberine improves the lipid-lowering efficacy. Metabolism 2008, 57, 1029-1037. [CrossRef]

124. Chan, J.C.; Piper, D.E.; Cao, Q.; Liu, D.; King, C.; Wang, W.; Tang, J.; Liu, Q.; Higbee, J.; Xia, Z.; et al. A proprotein convertase subtilisin/kexin type 9 neutralizing antibody reduces serum cholesterol in mice and nonhuman primates. Proc. Natl. Acad. Sci. USA 2009, 106, 9820-9825. [CrossRef]

125. Frank-Kamenetsky, M.; Grefhorst, A.; Anderson, N.N.; Racie, T.S.; Bramlage, B.; Akinc, A.; Butler, D.; Charisse, K.; Dorkin, R.; Fan, Y.; et al. Therapeutic RNAi targeting PCSK9 acutely lowers plasma cholesterol in rodents and LDL cholesterol in nonhuman primates. Proc. Natl. Acad. Sci. USA 2008, 105, 11915-11920. [CrossRef]

126. Chaudhary, R.; Garg, J.; Shah, N.; Sumner, A. PCSK9 inhibitors: A new era of lipid lowering therapy. World J. Cardiol. 2017, 9, 76-91. [CrossRef]

127. Graham, M.J.; Lemonidis, K.M.; Whipple, C.P.; Subramaniam, A.; Monia, B.P.; Crooke, S.T.; Crooke, R.M. Antisense inhibition of proprotein convertase subtilisin/kexin type 9 reduces serum LDL in hyperlipidemic mice. J. Lipid Res. 2007, 48, 763-767. [CrossRef]

128. Brunetti, L.; Gundry, M.C.; Goodell, M.A. DNMT3A in Leukemia. Cold Spring Harb. Perspect. Med. 2017, 7, a030320. [CrossRef]

129. Suetake, I.; Mishima, Y.; Kimura, H.; Lee, Y.H.; Goto, Y.; Takeshima, H.; Ikegami, T.; Tajima, S. Characterization of DNA-binding activity in the N-terminal domain of the DNA methyltransferase Dnmt3a. Biochem. J. 2011, 437, 141-148. [CrossRef]

130. Jurkowska, R.Z.; Rajavelu, A.; Anspach, N.; Urbanke, C.; Jankevicius, G.; Ragozin, S.; Nellen, W.; Jeltsch, A. Oligomerization and binding of the Dnmt3a DNA methyltransferase to parallel DNA molecules: Heterochromatic localization and role of Dnmt3L. J. Biol. Chem. 2011, 286, 24200-24207. [CrossRef]

131. Shivarov, V.; Gueorguieva, R.; Stoimenov, A.; Tiu, R. DNMT3A mutation is a poor prognosis biomarker in AML: Results of a meta-analysis of 4500 AML patients. Leuk. Res. 2013, 37, 1445-1450. [CrossRef]

132. Itzykson, R.; Kosmider, O.; Fenaux, P. Somatic mutations and epigenetic abnormalities in myelodysplastic syndromes. Best Pract. Res. Clin. Haematol. 2013, 26, 355-364. [CrossRef]

133. Jankowska, A.M.; Makishima, H.; Tiu, R.V.; Szpurka, H.; Huang, Y.; Traina, F.; Visconte, V.; Sugimoto, Y.; Prince, C.; O'Keefe, C.; et al. Mutational spectrum analysis of chronic myelomonocytic leukemia includes genes associated with epigenetic regulation: UTX, EZH2, and DNMT3A. Blood 2011, 118, 3932-3941. [CrossRef]

134. Vannucchi, A.M.; Lasho, T.L.; Guglielmelli, P.; Biamonte, F.; Pardanani, A.; Pereira, A.; Finke, C.; Score, J.; Gangat, N.; Mannarelli, C.; et al. Mutations and prognosis in primary myelofibrosis. Leukemia 2013, 27, 1861-1869. [CrossRef]

135. Traina, F.; Visconte, V.; Jankowska, A.M.; Makishima, H.; O’Keefe, C.L.; Elson, P.; Han, Y.; Hsieh, F.H.; Sekeres, M.A.; Mali, R.S.; et al. Single nucleotide polymorphism array lesions, TET2, DNMT3A, ASXL1 and CBL mutations are present in systemic mastocytosis. PLoS ONE 2012, 7, e43090. [CrossRef]

136. Grossmann, V.; Haferlach, C.; Weissmann, S.; Roller, A.; Schindela, S.; Poetzinger, F.; Stadler, K.; Bellos, F.; Kern, W.; Haferlach, T.; et al. The molecular profile of adult T-cell acute lymphoblastic leukemia: Mutations in RUNX1 and DNMT3A are associated with poor prognosis in T-ALL. Genes Chromosom. Cancer 2013, 52, 410-422. [CrossRef]

137. Gaidzik, V.I.; Schlenk, R.F.; Paschka, P.; Stolzle, A.; Spath, D.; Kuendgen, A.; von Lilienfeld-Toal, M.; Brugger, W.; Derigs, H.G.; Kremers, S.; et al. Clinical impact of DNMT3A mutations in younger adult patients with acute myeloid leukemia: Results of the AML Study Group (AMLSG). Blood 2013, 121, 4769-4777. [CrossRef]

138. Yuan, X.Q.; Peng, L.; Zeng, W.J.; Jiang, B.Y.; Li, G.C.; Chen, X.P. DNMT3A R882 Mutations Predict a Poor Prognosis in AML: A Meta-Analysis From 4474 Patients. Medicine (Baltimore) 2016, 95, e3519. [CrossRef] 
139. Kihara, R.; Nagata, Y.; Kiyoi, H.; Kato, T.; Yamamoto, E.; Suzuki, K.; Chen, F.; Asou, N.; Ohtake, S.; Miyawaki, S.; et al. Comprehensive analysis of genetic alterations and their prognostic impacts in adult acute myeloid leukemia patients. Leukemia 2014, 28, 1586-1595. [CrossRef]

140. Snetsinger, B.; Ferrone, C.K.; Rauh, M.J. Targeted, amplicon-based, next-generation sequencing to detect age-related clonal hematopoiesis. Methods Mol. Biol. 2019, in press.

141. Luthra, R.; Patel, K.P.; Reddy, N.G.; Haghshenas, V.; Routbort, M.J.; Harmon, M.A.; Barkoh, B.A.; Kanagal-Shamanna, R.; Ravandi, F.; Cortes, J.E.; et al. Next-generation sequencing-based multigene mutational screening for acute myeloid leukemia using MiSeq: Applicability for diagnostics and disease monitoring. Haematologica 2014, 99, 465-473. [CrossRef]

142. Marcucci, G.; Metzeler, K.H.; Schwind, S.; Becker, H.; Maharry, K.; Mrozek, K.; Radmacher, M.D.; Kohlschmidt, J.; Nicolet, D.; Whitman, S.P.; et al. Age-related prognostic impact of different types of DNMT3A mutations in adults with primary cytogenetically normal acute myeloid leukemia. J. Clin. Oncol. 2012, 30, 742-750. [CrossRef]

143. Brewin, J.N.; Horne, G.A.; Bisling, K.E.; Stewart, H.J.; Chevassut, T.J. Rapid detection of DNMT3A R882 codon mutations allows early identification of poor risk patients with acute myeloid leukemia. Leuk. Lymphoma 2013, 54, 1336-1339. [CrossRef]

144. Singh, R.R.; Bains, A.; Patel, K.P.; Rahimi, H.; Barkoh, B.A.; Paladugu, A.; Bisrat, T.; Ravandi-Kashani, F.; Cortes, J.E.; Kantarjian, H.M.; et al. Detection of high-frequency and novel DNMT3A mutations in acute myeloid leukemia by high-resolution melting curve analysis. J. Mol. Diagn. 2012, 14, 336-345. [CrossRef]

145. Shabbir, M.A.; Hao, H.; Shabbir, M.Z.; Wu, Q.; Sattar, A.; Yuan, Z. Bacteria vs. bacteriophages: Parallel evolution of immune arsenals. Front. Microbiol. 2016, 7, 1292. [CrossRef]

146. Dy, R.L.; Richter, C.; Salmond, G.P.; Fineran, P.C. Remarkable mechanisms in microbes to resist phage infections. Annu. Rev. Virol. 2014, 1, 307-331. [CrossRef]

147. Arutyunov, D.; Frost, L.S. F conjugation: Back to the beginning. Plasmid 2013, 70, 18-32. [CrossRef]

148. Ishino, Y.; Krupovic, M.; Forterre, P. History of CRISPR-Cas from encounter with a mysterious repeated sequence to genome editing technology. J. Bacteriol. 2018, 200. [CrossRef]

149. Hille, F; Charpentier, E. CRISPR-Cas: Biology, mechanisms and relevance. Philos. Trans. R. Soc. Lond. B Biol. Sci. 2016, 371, 20150496. [CrossRef]

150. Strich, J.R.; Chertow, D.S. CRISPR-Cas Biology and Its Application to Infectious Diseases. J. Clin. Microbiol. 2019, 57, e01307-18. [CrossRef]

151. Wright, A.V.; Nunez, J.K.; Doudna, J.A. Biology and applications of CRISPR systems: Harnessing nature's toolbox for genome engineering. Cell 2016, 164, 29-44. [CrossRef]

152. Yu, J.S.L.; Yusa, K. Genome-wide CRISPR-Cas9 screening in mammalian cells. Methods 2019, in press. [CrossRef]

153. Jinek, M.; Chylinski, K.; Fonfara, I.; Hauer, M.; Doudna, J.A.; Charpentier, E. A programmable dual-RNA-guided DNA endonuclease in adaptive bacterial immunity. Science 2012, 337, 816-821. [CrossRef]

154. Mali, P.; Esvelt, K.M.; Church, G.M. Cas9 as a versatile tool for engineering biology. Nat. Methods 2013, 10, 957-963. [CrossRef]

155. Cong, L.; Ran, F.A.; Cox, D.; Lin, S.; Barretto, R.; Habib, N.; Hsu, P.D.; Wu, X.; Jiang, W.; Marraffini, L.A.; et al. Multiplex genome engineering using CRISPR/Cas systems. Science 2013, 339, 819-823. [CrossRef]

156. Gasiunas, G.; Barrangou, R.; Horvath, P.; Siksnys, V. Cas9-crRNA ribonucleoprotein complex mediates specific DNA cleavage for adaptive immunity in bacteria. Proc. Natl. Acad. Sci. USA 2012, 109, E2579-E2586. [CrossRef]

157. Sternberg, S.H.; LaFrance, B.; Kaplan, M.; Doudna, J.A. Conformational control of DNA target cleavage by CRISPR-Cas9. Nature 2015, 527, 110-113. [CrossRef]

158. Sander, J.D.; Joung, J.K. CRISPR-Cas systems for editing, regulating and targeting genomes. Nat. Biotechnol. 2014, 32, 347-355. [CrossRef]

159. Joung, J.; Konermann, S.; Gootenberg, J.S.; Abudayyeh, O.O.; Platt, R.J.; Brigham, M.D.; Sanjana, N.E.; Zhang, F. Genome-scale CRISPR-Cas9 knockout and transcriptional activation screening. Nat. Protoc. 2017, 12, 828-863. [CrossRef]

160. Farhat, S.; Jain, N.; Singh, N.; Sreevathsa, R.; Dash, P.; Rai, R.; Yadav, S.; Kumar, P.; Sarkar, A.; Jain, A.; et al. CRISPR-cas 9 directed genome engineering for enhancing salt stress tolerance in rice. Semin. Cell Dev. Biol. 2019, in press. [CrossRef] 
161. Kaushik, I.; Ramachandran, S.; Srivastava, S.K. CRISPR-Cas9: A multifaceted therapeutic strategy for cancer treatment. Semin. Cell Dev. Biol. 2019, in press. [CrossRef]

162. O'Geen, H.; Henry, I.M.; Bhakta, M.S.; Meckler, J.F.; Segal, D.J. A genome-wide analysis of Cas9 binding specificity using ChIP-seq and targeted sequence capture. Nucleic Acids Res. 2015, 43, 3389-3404. [CrossRef]

163. O'Geen, H.; Yu, A.S.; Segal, D.J. How specific is CRISPR/Cas9 really? Curr. Opin. Chem. Biol. 2015, $29,72-78$. [CrossRef]

164. Molla, K.A.; Yang, Y. CRISPR/Cas-mediated base editing: Technical considerations and practical applications. Trends Biotechnol. 2019, in press. [CrossRef]

165. Tadic, V.; Josipovic, G.; Zoldos, V.; Vojta, A. CRISPR/Cas9-based epigenome editing: An overview of dCas9-based tools with special emphasis on off-target activity. Methods 2019, in press.

166. Kimberland, M.L.; Hou, W.; Alfonso-Pecchio, A.; Wilson, S.; Rao, Y.; Zhang, S.; Lu, Q. Strategies for controlling CRISPR/Cas9 off-target effects and biological variations in mammalian genome editing experiments. J. Biotechnol. 2018, 284, 91-101. [CrossRef]

167. Guilinger, J.P.; Thompson, D.B.; Liu, D.R. Fusion of catalytically inactive Cas9 to FokI nuclease improves the specificity of genome modification. Nat. Biotechnol. 2014, 32, 577-582. [CrossRef]

168. Slaymaker, I.M.; Gao, L.; Zetsche, B.; Scott, D.A.; Yan, W.X.; Zhang, F. Rationally engineered Cas9 nucleases with improved specificity. Science 2016, 351, 84-88. [CrossRef]

169. Kleinstiver, B.P.; Pattanayak, V.; Prew, M.S.; Tsai, S.Q.; Nguyen, N.T.; Zheng, Z.; Joung, J.K. High-fidelity CRISPR-Cas9 nucleases with no detectable genome-wide off-target effects. Nature 2016, 529, 490-495. [CrossRef]

170. Tycko, J.; Myer, V.E.; Hsu, P.D. Methods for optimizing CRISPR-Cas9 genome editing specificity. Mol. Cell 2016, 63, 355-370. [CrossRef]

171. O’Reilly, D.; Kartje, Z.J.; Ageely, E.A.; Malek-Adamian, E.; Habibian, M.; Schofield, A.; Barkau, C.L.; Rohilla, K.J.; DeRossett, L.B.; Weigle, A.T.; et al. Extensive CRISPR RNA modification reveals chemical compatibility and structure-activity relationships for Cas9 biochemical activity. Nucleic Acids Res. 2019, 47, 546-558. [CrossRef]

172. Hendel, A.; Bak, R.O.; Clark, J.T.; Kennedy, A.B.; Ryan, D.E.; Roy, S.; Steinfeld, I.; Lunstad, B.D.; Kaiser, R.J.; Wilkens, A.B.; et al. Chemically modified guide RNAs enhance CRISPR-Cas genome editing in human primary cells. Nat. Biotechnol. 2015, 33, 985-989. [CrossRef]

173. Xiao, J.; Deng, Y.M.; Liu, X.R.; Cao, J.P.; Zhou, M.; Tang, Y.L.; Xiong, W.H.; Jiang, Z.S.; Tang, Z.H.; Liu, L.S. PCSK9: A new participant in lipophagy in regulating atherosclerosis? Clin. Chim. Acta 2019, 495, 358-364. [CrossRef]

174. Briata, P.; Di Blas, E.; Gulisano, M.; Mallamaci, A.; Iannone, R.; Boncinelli, E.; Corte, G. EMX1 homeoprotein is expressed in cell nuclei of the developing cerebral cortex and in the axons of the olfactory sensory neurons. Mech. Dev. 1996, 57, 169-180. [CrossRef]

175. Uehara, T.; Choong, C.J.; Nakamori, M.; Hayakawa, H.; Nishiyama, K.; Kasahara, Y.; Baba, K.; Nagata, T.; Yokota, T.; Tsuda, H.; et al. Amido-bridged nucleic acid (AmNA)-modified antisense oligonucleotides targeting alpha-synuclein as a novel therapy for Parkinson's disease. Sci. Rep. 2019, 9, 7567. [CrossRef]

(C) 2019 by the authors. Licensee MDPI, Basel, Switzerland. This article is an open access article distributed under the terms and conditions of the Creative Commons Attribution (CC BY) license (http://creativecommons.org/licenses/by/4.0/). 